\title{
IMPACT OF FOREIGN EXCHANGE RISK ON INVESTMENT PORTFOLIO PERFORMANCE IN LATIN AMERICAN STOCK INDEXES
}

\author{
Iván Arribas ${ }^{1}$, Jairo González-Bueno ${ }^{2}$, Francisco Guijarro ${ }^{3}$, Javier Oliver $^{4}$ \\ ${ }^{I}$ Faculty of Economy, Universitat de Valencia, Avda Tarongers, s/n, 46022, Valencia, Spain \\ ${ }^{2}$ Faculty of Business Administration, Universidad Pontificia Bolivariana, \\ Km 7 Via Piedecuesta, Bucaramanga, Santander, Colombia \\ $3,{ }^{4}$ Faculty of Business Administration and Management, Universitat Politècnica de València, \\ Campus de Vera, Camino de Vera, s/n, 46022 València, Spain \\ E-mails: ${ }^{1}$ van.arribas@uv.es; ${ }^{2}$ jairoa.gonzalez@upb.edu.co; \\ ${ }^{3}$ fraguima@esp.upv.es (corresponding author); ${ }^{j}$ jaolmun@ade.upv.es
}

\begin{abstract}
This article aims to analyze whether investing in international assets, and fluctuations in their own currencies, allow the possibility of structuring diversified investment portfolios that would not only maximize the expected return, but also minimize risk. For this, it is evaluated the impact of currency risk on the profitability of investment portfolios in the stock indexes in Argentina, Brazil, Chile, Colombia, Mexico and Peru from the point of view 6 investors (one American and five located in each of these countries) during the period 2002-2014.
\end{abstract}

Keywords: exchange rates, financial crisis, stock indexes, volatility and correlation coefficient, forex, financial markets.

JEL Classification: G11; G12.

\section{Introduction}

The Great Recession of 2007-2009 has led to periods of high volatility in local and international stock markets, causing investors who want to minimize the risk and cope with fluctuations in stock prices, structured investment portfolios including assets fulfilling the role of shelters value and/or the role of hedging instruments (Santillán, Carlos 2013).

The expansion of the world economy presented in the last decade, has been linked to the remarkable growth and liberalization of capital markets in emerging and developing economies, as well technological advances have made the investment process easier and open to equities. Today, an investor has more options in building investment portfolios to reap the benefits of greater international diversification as a result of non-synchronous co-movements of national economies and stock markets (Switzer, Tahaoglu 2015).

Globalization has been a key factor in promoting institutional reforms in emerging factor, as it has promoted the financial development and economic growth of these states (Mishkin 2009). Moreover, while the financial markets has been correlated, implying that the work of portfolio diversification is now more complex than simply selecting the mix of different types of assets that provides the local market (Maya 2011).
Investing internationally offers greater diversification than done nationally. Early advocates of international diversification are Grubel (1968) and Levy and Sarnat (Levy, Sarnat 1970), which used the mean-variance model. Also, Errunza et al. (1999) analyzed the benefits of building an investment portfolio that mimics foreign indexes to achieve higher performance without direct overseas exposure. Estrada (2008) examines the benefits of international diversification in the application of fundamental indexing, and found significant benefits of diversification using low-cost index funds and ETFs. Eun et al. (2008) analyzed international portfolio diversification in Australia, Canada, France, Germany, Hong Kong, Italy, Japan, the Netherlands, the UK and the US, and conclude that for an US investor, invest in shares of smaller capitalization companies will provide significant diversification benefits in comparison to investing in stocks of companies with the largest capitalization. Finally, Berger et al. (2013) show that regional and frontier markets offer diversification benefits in a context of mean-variance. The results covering the mean-variance model reveals that market volatility border is largely idiosyncratic part. In addition, analysis of the dynamics of trade suggests that investors are interested in assets that offer exposure to

(C) 2016 The Authors. Published by VGTU Press. This is an open-access article distributed under the terms of the Creative Commons Attribution License (CC-BY 4.0), which permits unrestricted use, distribution, and reproduction in any medium, provided the original author and source are credited. 
frontier markets and, consequently, a possible lack of liquidity does not seem to be a concern.

International investments have had good results on average, but in expressing their returns in local currencies, the benefits of international diversification has not always offset by the assumed risk return including the volatility of the exchange rate, as well as the inherent to each type of investment (Maya et al. 2011).

This paper aims to analyze whether investing in international assets, and fluctuations in their own currencies, allow the possibility of structuring diversified investment portfolios that would not only maximize the expected return, but also minimize risk. For this,it is evaluated the impact of currency risk on the profita-bility of investment portfolios in the stock indexes in Argentina, Brazil, Chile, Colombia, Mexico and Peru from the point of view 6 investors (one American and five located in each of these countries) during the period 2002-2014.

In the first part of this paper it is done a brief theoretical exploration of financial crises and how they have affected the volatility of exchange rates and therefore the benefits of international diversification. In the second part, it will take place an analysis of the evolution of stock indexes and the currencies of Argentina, Brazil, Chile, Colombia, Mexico, Peru, United States and Europe during the period 2002-2014 and its relationship with financial crises international. It is analyzed the correlation between Latin American stock markets and the Americans and Europeans as well as the correlation of the currencies of Latin American emerging economies and the US dollar and the Euro. The third part will focus on the analysis of the impact of currency risk on the profitability of investment in Latin American stock indexes, from the point of view 6 investors (one American and five located in each of these countries). In the fourth part, finally, it will be presented the most important conclusions of the study.

\section{Theoretical framework}

In the financial literature, portfolio theory by Markowitz $(1952,1959,1987,1991)$ provides a model for obtaining efficient portfolios, from the rational behavior of the investor which is to maximize returns and minimize risk. This was the starting point of Modern Portfolio Theory, which has been a fundamental theoretical reference in the selection of portfolios, leading to multiple developments and referrals. However, the design of investment portfolios currently confronts situations in which more and more sophisticated products, and at the same time, it is possible to invest beyond the borders of a country.
The economic and financial crises usually are linked to imbalances in exchange rates, however, there are other underlying factors leading to an exchange fragility in a state, among which are the relationships that this variable keeps with other economic variables, both local and its principal economic and financial partners. These variables are indicators of cointegration and long-run exchange rate equilibrium, which usually are broken, exposing a country to high volatility and exchange rate risk, providing feedback to the fundamental remaining variables and so curbing economic development (Sosa, Ortiz 2015).

Episodes of increased global risk aversion, known in English as episodes "Risk-off" have been more frequent and severe from 2007, causing that the perception of investor risk is high, leading to liquidate their positions in riskier assets, to allocate these resources into more liquid assets, or lower risk, such as sovereign bonds. Indeed, De Bock and De Carvalho (2015) analyzed the determinants of returns of currencies as investors around the world want to reduce at the same time, their risk exposure. These authors, based on the rate of market volatility Chicago-VIX options, determined that after the start of the episodes "Risk-off", the high-yielding currencies, and those whose returns have a higher beta to the VIX or the exchange rate AUD / JPY, tend to have higher depreciation relative to the US dollar. Strong current account balances and net foreign asset positions, are the factors related to depreciation and currency appreciations.

As for individual currencies, De Bock and De Carvalho (2015) concluded that the Swiss franc and Japanese yen tend to appreciate against the US dollar during episodes of "Risk-off". In contrast the currencies of Australia, Brazil, Canada, Chile, Colombia, India, Indonesia, Korea, Malaysia, Mexico, New Zealand, Peru, the Philippines, Singapore, South Africa, Sweden, Turkey, Ukraine and the UK, tend to depreciate over the mentioned episodes.

Ranaldo and Söderlind (2010) provided an empirical study refered to currencies that have the attributes of being safe-haven currencies, and based on the evolution and behavior that some of these occurred during the period 1993 to 2008, concluded that the Swiss franc and the Japanese yen appreciated against the US dollar, therefore, show outperformance when the price of shares in the United States fell, or when the price of Treasuries of US and volatility exchange rate increases. Meanwhile, the Euro has similar properties, but weaker proportions; and with respect to the pound sterling, they consider that it should not be considered a safe haven currency. 
Cordella and Gupta (2015), analyze currency movements during different economic cycles. To do this, they developed an index of cyclical currency and examined the correlation between the cyclical components of GDP and the exchange rate, and classified the coins as procyclical if seen in the good times, countercyclical if seen in the bad times, and acyclic otherwise. The conclusion reached is that countries exporting raw materials and experienced procyclical capital flows tend to have pro-cyclical currencies, causing restrictions on their capital accounts to reduce the degree of procyclicality. However, in the last decade, it has presented a disconnect between the cyclical nature of currency and monetary policy, reflecting a decrease in fear of floating, which is partly attributable to an improvement in the position of net international investment .

It is necessary, therefore, to analyze the impact of different currencies in the composition of a diversified international portfolio. This should take into account the globalization of economies and the transmission of financial crises across countries causing positive correlations between currencies. It is necessary the use of products of hedging risk currency as forwards, futures and options exchange rates.

The benefits of international diversification depends mainly on the stock market correlations. Quinn and Voth (2008) concluded that over the past century, financial liberalization was accompanied by a higher correlation of domestic stock markets to foreigners. In addition, countries open economies kept higher correlation levels than those presented in closed economies. As more and more countries open up to foreign ca-pital, correlations tend to grow, thereby deteriorating the potential gains from diversification, which reduces the attractiveness and convenience of international diversification. However, despite the increase of fluctuations in stock markets, investors can still make considerable profits through diversification, when foreign investment precedes the local investments, as these have lower correlations compared to domestic investments.

In the same line of previous research, Bellalah et al. (2011) conducted an empirical review of the impact of the integration of the stock market in the efficiency of international diversification. To do this, first they examined the evolution of the correlation of 31 stock indexes of 5 developed countries (United States, Canada, Britain, France and Japan) and 26 emerging countries (Indonesia, Korea, Malaysia, Philippines, Sri Lanka, Taiwan, Thailand, Argentina, Brazil, Chile, Colombia, Mexico, Peru, Venezuela, Czech Republic, Hurgaría, Poland, Russia, China, India, Pakistan, Jordan, Turkey, Israel,
Egypt and Morocco). This test showed the presence of a low correlation between emerging and developed markets, hence the low correlation demonstrates that international diversification is still considered as an alternative of efficient allocation in terms of volatility reduction and performance improvement. In contrast, the correlation between developed markets is higher and therefore diversification gains are less important. Second, it were applied different methods related to the cointegration tests (multivariate, bivariate), which showed that some economic blocs are composed mainly of developed markets, which leads to reduce the attractiveness of international diversification. The end result of the research showed that the developed countries get a better international diversification of their portfolios in emerging markets rather than developed markets.

Meanwhile, Switzer and Tahaoglu (2014), through the mean-variance model analyzed the benefits of international diversification during the period August 1996 to July 2013 for an investor in the United States, whose investment process is performed based on the quality of corporate governance and the development and market size. The authors concluded that US investors can achieve significant gains in building efficient portfolios by investing in developed and emerging economies. Also, they found evidence that the addition of emerging countries in the investment opportunity set containing assets of developed countries provides additional diversification benefits.

As can be seen, diversification is the main foundation of the theory of Markowitz Portfolio Selection (Markowitz 1952, 1959, 1987, 1991), and is a concept of risk reduction that involves the distribution of investment among different financial instruments, sectors and other categories investment. In simpler terms, diversification can be achieved by investing in different stocks, different asset classes (eg bonds, real estate, etc.) and/or raw materials such as gold or oil. In this vein, Baruník et al. (2015), using the approach of wavelets conducted an analysis of a time series in the frequency domain and time of dynamic correlations price (intraday and daily) of the gold, oil and the S\&P500 index for the period 1987 to 2012 . The researchers found evidence that heterogeneity between the correlations of the three aforementioned assets is dominant in times of economic recession and financial turmoil. Heterogeneity prevails during most of the precrisis in correlations between gold and the S\& P 500 index. Moreover, after the 2008 crisis, the correlations between the three assets increase and becomes homogeneous. 
Andersen (1987), determined that the construction of efficient portfolios considers both returns as currency fluctuations, however, has limitations, as it should be based on historical statistics of returns and movements in exchange rates, which can be corrected using expected future variations in estimates, but without final results guaranteed. Similarly, another limitation is that often the greatest return portfolio can also be the most risky.

Abken and Shrikhande (1997) examined the impact of currency hedging in internationally diversified investment portfolios on 7 industrialized countries and argue that through the hedge with forward contracts over the exchange rate is possible to reduce the risk and and unpredictable losses of the individual performances of the portfolio; however, the results are not consistent across study periods. The authors conclude that the exchange hedging needs better models and techniques for the parameters of prediction of the model optimization which required further research.

Based on the foregoing, Maurer and Valiani (2003) analyzed from the point of view of a German investor, the effectiveness of the exchange risk control for portfolios of stocks and bonds internationally diversified in the markets of UK, Germany, Japan, Switzerland and the US, during the period January 1985 to December 2002. The researchers suggest that, in this case, European sales options that are "in the money", can replace the forwards to reduce exposure to currency risk; however, in much of the literature reviewed, the coverages are made through forwards in order to simplify the models.

Meanwhile, Walker (2008), studies the perspective of an emerging market investor investing in a portfolio of global actions, and for which coverage should involve increasing expected returns. The author asks the question whether coverage for an investor in emerging country is a "free lunch" and concludes that it is not, because the strong currencies act as natural loss hedgings of global (and local) holdings because they tend to appreciate against the currencies of emerging countries when the performance of the global equities portfolio is negative. Therefore, in this case, currency coverage increases the volatility, and thus increases the expected return.

\section{Evolution of the main stock markets in Latin America, USA and Europe and their respective currencies in the period from 2002 to 2014}

For the analysis presented below, it was used the value data daily closing stock indices of Mexico (IPC), Brazil (BOVESPA), Chile (IPSA), Colombia
(IGBC-COLCAP), Peru (IGBVL), Argentina (Merval), United States (S\&P500) and Europe (EURO STOXX 50) during the period January 2002 to December 2014, and the daily closing prices of the exchange rates of the Mexican peso (USD/MXN) Brazilian Real (USD/BRL), Chilean peso (USD / CLP), Colombian Peso (USD/COP) Peruvian Nuevo Sol (USD/PEN), Argentine Peso (USD/ARS) and Euro (USD/EUR) during the period January 2002 to December 2014. The above information was obtained from Economatica ${ }^{\circledR}$.

\subsection{Volatility}

The volatility of the stock market has a negative effect on the extent to which short-term variations do not reflect correctly the equilibrium values of the financial asset. In this sense, market volatility is related to the level of risk, and depends on transaction systems used. Inefficiencies in markets mean that prices take time to collect new information (Arbeláez, Zuluaga, Guerra 2002). Moreover, in a globalized market, volatility it depends on factors related to domestic markets and the international situation.

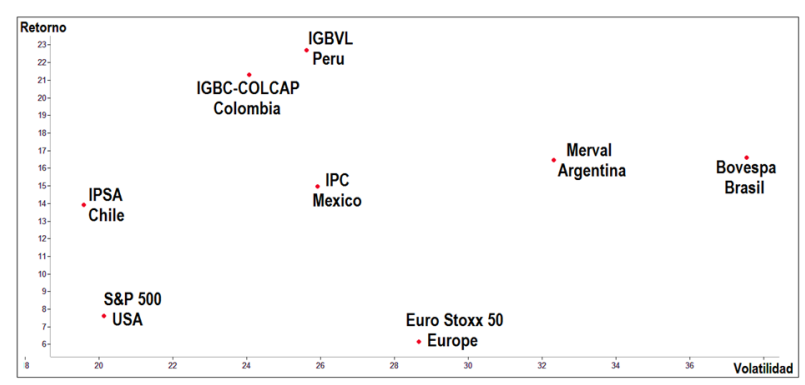

Fig. 1. Dominance Indexes Brazil, Mexico, Chile, Colombia, Peru, Argentina, United States and Europe (2002-2014) (Source: Economatica ${ }^{\circledR}$ and authors)

A simplified way to measure volatility and thus to perceive the risk of the stock market, is to assess the variance of returns of stock indices (the standard deviation). This indicator reflects how stable is the performance over time and with what frequency varies. Another interesting analysis and which will be developed in this work is to compare the profitability-risk binomial of different international stock indices. This study is more complete than the simple calculation of volatility, because it incorporates to the analysis, information related to the gained profitability.

Figure 1 presents the chart dominance, in which it is made a comparison of risk and return on equity indices of stock markets of Brazil, Mexico, Chile, Colombia, Peru and Argentina, the US and Europe in the period July 2002 to December 2014. It is found that the stock market that offers higher 
expected returns is Peru, with a medium level of risk compared to the other markets analyzed; the stock market that offers less risk is Chile, which also exceeds profitability by American and European markets, making it a dominant and attractive rate for an investor who want to minimize the risk from a given level of profitability. On the other hand, it is worth highlighting the high yields obtained in all analyzed markets, always positive and up to almost $25 \%$

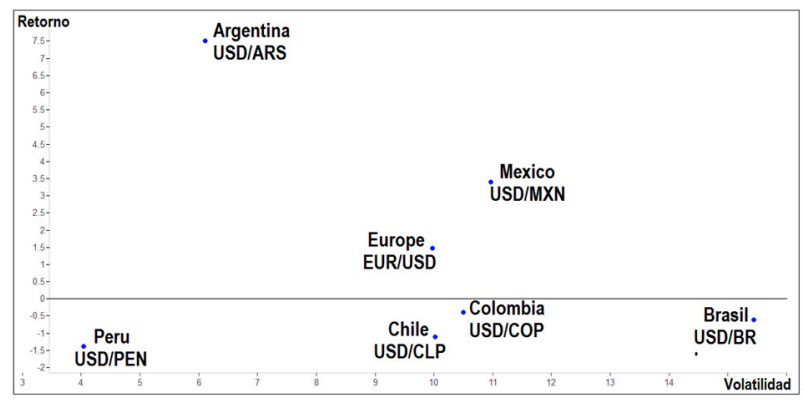

Fig. 2. Dominance Exchange in Brazil, Mexico, Chile, Colombia, Peru, Argentina, United States and Europe

(2002-2014) (Source: Economatica ${ }^{\circledR}$ and authors)

After the foregoing, Figure 2 presents the chart ominance of the exchange rates of the economies mentioned for the period 2002-2014. It is found that the Argentine peso is a currency which has submitted the highest level of depreciation $(7.50 \%)$, and therefore is less profitable currency of the selected sample, with a low level of volatility compared to other types of change. This same behavior presents the Mexican peso, which for the past 12 years, has depreciated by an average of $3.41 \%$. In contrast, the Peruvian Nuevo Sol, is the most valued currency, which makes it the most profitable currency of the 7 analyzed currencies $(1.38 \%)$. Likewise, the Chilean Peso, Colombian Peso, Euro and the Brazilian Real is appreciated during the observation window analyzed.

It was performed an analysis of the behavior of the volatility of each index, but to better observe the trend of each of them on the same graph, it was taken as base 100 for the first month (July 2002) and then there were determined the price changes period to period. In Figure 3, it can be seen that in the case of Latin America, the markedly favorable conjuncture of 2003-2007, based on an unusual combination of financial boom, boom outstanding commodity prices and high level of remittances migrant workers (Ocampo 2009), allowed during this period, the stock markets of these economies present a better performance compared to European and American market.

Also, it is evident that in general most of the indices showed a downward trend during 2008, a period characterized by high volatility and global uncertainty, generated by the international financial crisis which affected particularly the United States and Europe. However, during 2009 and 2010, the indices showed an upward trend, influenced by optimism and expectations of investors regarding the economies of emerging countries. Throughout the year 2011, the indices show a downward trend again, mainly marked by the debt crisis affecting several countries in the European Union, particularly Greece, Portugal, Italy and Spain, fears of a recession in the area euro, and slowing growth in Asian economies, particularly China.

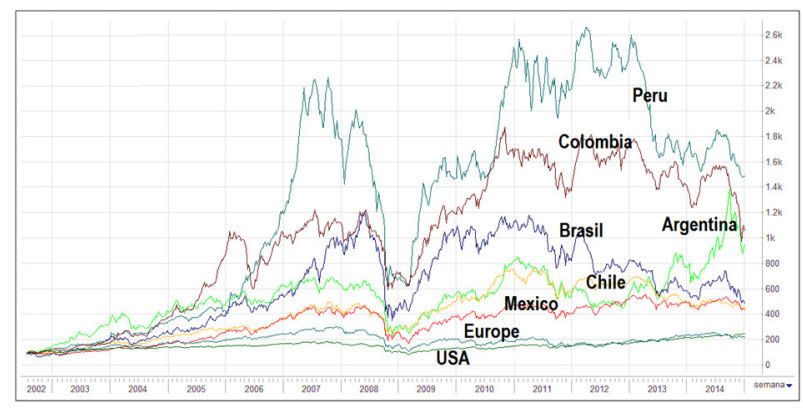

Fig. 3. Behavior of Stock Market Indices of stock markets of Brazil, Mexico, Chile, Colombia, Peru, Argentina, United States and Europe (2002-2014) (Source:

Economatica ${ }^{\circledR}$ and authors)

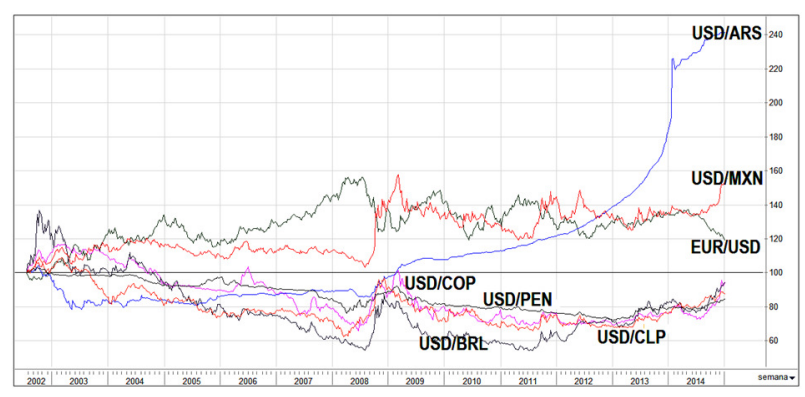

Fig. 4. Behavior Exchange rates of Brazil, Mexico, Chile, Colombia, Peru, Argentina, United States and Europe (2002-2014) (Source: Economatica ${ }^{\circledR}$ and authors)

Using the same methodology described in the preceding paragraph, the Figure 4 presents the growth chart (base 100) of the Euro and major economies of Latin America against US dollar. It is clear that the Mexican peso depreciated against the US dollar over the 12 years analyzed. Moreover, it is interesting to see the behavior reflected by the Argentine Peso, which from 2008 has presented an exponential depreciation as a result of the financial policies issued by the government of President Cristina Kirchner to mitigate the effects of the international financial crisis the year 2007-2011. These 
measures include: a) The reduction in bank reserve requirements in both US dollars and Argentinian Pesos; B) to provide liquidity in domestic currency by daily repurchase of bonds issued by the Central Bank; C) The provision of liquidity in foreign currency through exchanges with the Central Bank of Brazil and China; D) The imposition of measures to prevent the outflow of foreign capital; and E) Incentives for the repatriation of assets (Pastor, Wise, 2015).

In line with this, the consolidation of inflation rates that exceeded nominal devaluation and the difficulties of maintaining the trade surplus, led the Argentine government to devalue its currency. Likewise, the price increase caused the reappearance of negative real interest rates, stimulating investments in foreign currencies. These factors contributed to that from 2010 capital flight intensified and Central Bank reserves fell (e.g. Gaggero et al. 2015).

Also, by analyzing the behavior of the other exchange rates it shows that the Colombian peso, Chilean peso, the Peruvian Nuevo Sol and the Brazilian Real, were appreciated during the period from 2002 to 2014 , as a result of increased exports raw materials, the increase of resource flows of foreign direct investment (FDI), the increase of remittances from abroad, among others.

Figures 3 and 4 show that at times, as in 2008, the markets of different countries and their currencies move in the same direction. On the other hand, the strength of the trends and volatility, as described above, is much more pronounced in Latin America than in the United States or European markets. And this is true throughout the whole period analyzed. To check how the markets move in a rhythmic and analyze the degree of integration thereof is necessary to perform a correlation analysis.

\subsection{Correlation analysis}

Increasing international financial integration needs to be analyzed, as to the extent there is financial integration of stock markets, the countries' returns become more correlated, therefore, they tend to react together to the same micro and macroeconomic factors, which will decrease the benefits of diversifying portfolios conformed by assets of these markets. Table 1 shows the correlation matrix of the 8 selected stock indexes during the period January 2002 to December 2014. As you can see, there is not negative correlations, but there is no perfectly positive relationships between different indexes, the highest is 0.86 between the United States and Europe, and the less positive is between Colombia and Chile with 0.44 . This leads us to conclude that the stock markets with higher correlation (greater financial integration) are the Americans and Europeans, followed by Mexicans and Americans, and Brazilians and Mexicans.

Table 1. Correlation matrix of stock indices of stock markets in Brazil, Mexico, Chile, Colombia, Peru, Argentina, United States and Europe (2002-2014) (Source: Economatica ${ }^{\circledR}$ and authors)

\begin{tabular}{lllllllll} 
& EUR & CO & BR & PE & MX & CL & AR & US \\
\hline EUR & 1.00 & 0.52 & 0.66 & 0.48 & 0.75 & 0.57 & 0.58 & 0.86 \\
\hline CO & 0.52 & 1.00 & 0.58 & 0.44 & 0.61 & 0.52 & 0.46 & 0.47 \\
\hline BR & 0.66 & 0.58 & 1.00 & 0.55 & 0.70 & 0.69 & 0.56 & 0.68 \\
\hline PE & 0.48 & 0.44 & 0.55 & 1.00 & 0.60 & 0.53 & 0.51 & 0.49 \\
\hline MX & 0.75 & 0.61 & 0.70 & 0.60 & 1.00 & 0.62 & 0.61 & 0.78 \\
\hline CL & 0.57 & 0.52 & 0.69 & 0.53 & 0.62 & 1.00 & 0.53 & 0.57 \\
\hline AR & 0.58 & 0.46 & 0.56 & 0.51 & 0.61 & 0.53 & 1.00 & 0.50 \\
\hline US & 0.86 & 0.47 & 0.68 & 0.49 & 0.78 & 0.57 & 0.50 & 1.00 \\
\hline
\end{tabular}

Table 2. Correlations matrix exchange rate USD/BRL, USD/MXN, USD/CLP, USD/COP, USD/PEN, USD/ARS and EUR/USD (2002-2014) (Source: Economatica ${ }^{\circledR}$ and authors)

\begin{tabular}{lcccrrrr} 
& \multicolumn{1}{c}{ USD/ARS } & USD/MXN & EUR/USD & USD/COP & USD/BRL & USD/CLP & \multicolumn{2}{c}{ USD/PEN } \\
\hline USD/ARS & 1.00 & 0.21 & -0.11 & 0.14 & 0.26 & 0.22 & 0.12 \\
\hline USD/MXN & 0.21 & 1.00 & -0.49 & 0.53 & 0.55 & 0.60 & 0.42 \\
\hline EUR/USD & -0.11 & -0.49 & 1.00 & -0.38 & -0.35 & -0.48 & -0.29 \\
\hline USD/COP & 0.14 & 0.53 & -0.38 & 1.00 & 0.52 & 0.46 & 0.52 \\
\hline USD/BRL & 0.26 & 0.55 & -0.35 & 0.52 & 1.00 & 0.46 & 0.30 \\
\hline USD/CLP & 0.22 & 0.60 & -0.48 & 0.46 & 0.46 & 1.00 & 0.39 \\
\hline USD/PEN & 0.12 & 0.42 & -0.29 & 0.52 & 0.30 & 0.39 & 1.00 \\
\hline
\end{tabular}



Table 2 presents the correlation matrix of the main Latin American currencies and the Euro in terms of the US dollar during the period January 2002 to December 2014. Compared to the correlation analysis of stock indices, it appears that some currency pairs do have negative correlations. The currencies that have a high degree of positive linear correlation, are the USD/MXN and USD/CLP (0.60), and the less positive is between the USD/ARS and the USD/PEN (0.12). This allows us to infer that the economies with the highest correlation in their exchange rates (greater financial integration of their exchange rates) are Mexicans and Chileans, followed by Argentina and Peru.

By contrast, the currencies that have a high degree of negative linear correlation, are the USD/MXN and the EUR/USD (-0.49) and the less negative is between the USD/ARS and the EUR/USD (-0.11). As it is observed, economies with lower correlation in their exchange rates (less financial integration of their exchange rates) are Mexicans and Europeans, followed by Argentines and Europeans.

\section{Impact of currency risk on the profitability of investment portfolios in Latin American stock indices for an investor of the United States and five investors in Latin America}

Investing internationally offers greater diversification than done nationally. However, it is important to analyze whether investing in international assets, and fluctuations in their own currencies, allow the possibility of structuring diversified investment portfolios that would not only maximimizar the expected return, but also minimize risk. Therefore, to analyze the impact of currency risk on the profitability of investment portfolios in Latin American stock indexes, it is worked under the assumption that an investor from the US, Argentina, Brazil, Chile, Colombia, Mexico and Peru, in 2002 has available 100,000 USD, which he turns into local currency, and invests it in equal proportions in the stock indexes of Mexico (IPC), Brazil (BOVESPA), Chile (IPSA), Colombia (IGBC-COLCAP), Peru (IGBVL) and Argentina (Merval), for a period of 12 years.

Figure 5 presents the behavior of the nominal return of the portfolios mentioned in the preceding paragraph. It was observed that during the period analyzed, the Mexican investor has the best performance in terms of nominal income from investment portfolios; however, it is overtaken by the Argentine investor, which obtains a better performance from the year 2012. Likewise, it is perceived that the Brazilian investor has the lowest performance in nominal yields in most of the analyzed years.

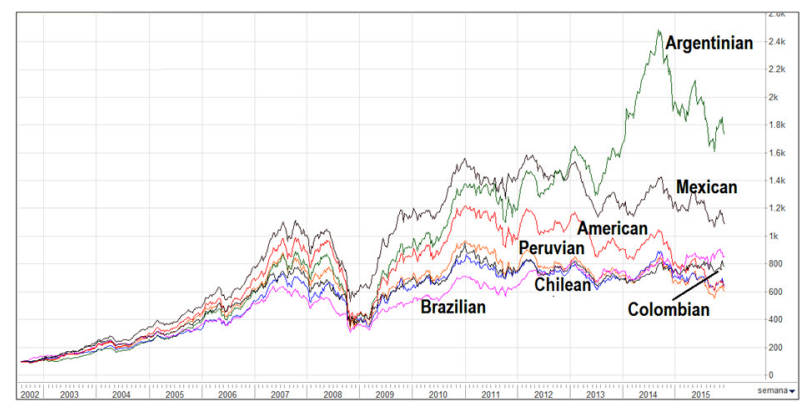

Fig. 5. Behavior of the nominal return of investment portfolios in Latin American equity indices for an investor of the United States, Argentina, Brazil, Chile, Colombia, Mexico and Peru (2002-2014)

(Source: Economatica ${ }^{\circledR}$ and authors)

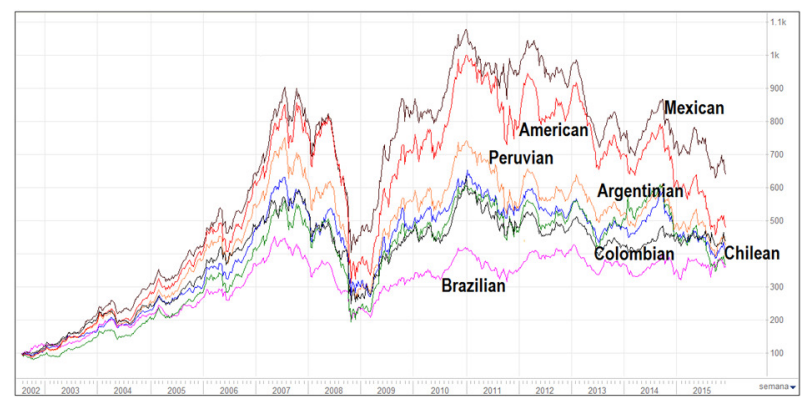

Fig. 6. Behavior of the Real Return on Investment Portfolio Indexes for Latin American equity investor of the United States, Argentina, Brazil, Chile, Colombia, Mexico and Peru (2002-2014)

(Source: Economatica ${ }^{\circledR}$ and authors)

Meanwhile, Figure 6 allows us to analyze the evolution of the real profitability of investment portfolios indicated. Compared to the analysis presented in the previous paragraph, it is evident that the real return of the Argentine investor becomes one of the lowest in the sample. This is because in the last 12 years, inflation of southern country is located in an annual average of $21.38 \%$, causing increased uncertainty, which adversely affects the expected return on investment and therefore growth the long run.

Continuing with the analysis of Figure 5, it follows that the investor who submitted the best performance in profitability in terms of the amount of goods and services that can be purchased (purchasing power), was the Mexican, followed by the American and the Peruvian. Likewise, it is evident that from the point of view of the evolution of the nominal and real return, the Brazilian investor has the lowest performance over the 12 years analyzed. 


\section{Conclusions}

The recent global crisis in financial markets brought with it periods of high volatility in local and international stock markets and exchange rates,causing investment decisions were every day more difficult because they are framed in a context of high global uncertainty.

The behavior of the last 12 years of stock market indices in the United States, Europe and major emerging economies of Latin America, reflect that the stock prices on the stock markets are increasingly affected by integration and financial liberalization, resulting in volatility of macroeconomic variables, unexpected fluctuations in the exchange rate and increases in interest rates. During the period 2002-2014, the stock market offering higher expected returns is Peru (24.59\%), with a risk level of $25.62 \%$, and the market that offers the lowest expected return is the European $(6,15 \%)$, with a level of volatility of $28.67 \%$. For its part, it is found that the Argentine peso is a currency which has submitted the highest depreciation level $(7.50 \%)$, and the Peruvian Nuevo Sol, is the most valued currency, which makes it the most profitable currency of 7 currencies analyzed (1.38\%).

In analyzing the impact of currency risk over the profitability of global investment portfolios in Latin American stock indices, it appears that over the period analyzed, the Mexican investor has the best performance in terms of nominal income from investment portfolios; however, it is overtaken by the Argentine investor, which obtains a better performance from the year 2012. However, when examining the evolution of investment portfolios from the standpoint of the real profitability, it is evident that the Argentine investor happened to be one of the performers with the lowest performing, due to high levels of inflation that have occurred in that country in recent years.

Based on the arguments that have been raised, it is evident that the Latin American investor who wants to reap the benefits of international diversification, must examine whether the investment in global assets, and fluctuations in their own currencies, will provide the possibility of structuring portfolios of investment with assets that meet the role of value shelters and / or the role of hedging instruments.

Likewise, the scope of this article is limited to analysis of portfolios of global investment portfolios in Latin American stock indices, however, remains open the ability to analyze whether the presented results are still obtained for investment portfolios that include equity indices of advanced economies and fixed income assets internationally.

\section{References}

Abken, P.; Shrikhande, M. 1997. The Role of Currency Derivatives in Internationally Diversified Portfolios. Federal Reserve Bank of Atlanta Economic Review (3): 34-59.

Andersen, J. 1987. Currency and interest rate hedging. A user's guide to options, futures, swaps \& forward contracts. (2a ed.). New York, NY: New York Institute of Finance.

Arbeláez, M. A.; Zuluaga, S.; Guerra, M. L. 2002. El mercado de capitales colombiano en los noventa y las firmas comisionistas de bolsa. Bogotá: Alfaomega Grupo Editor.

Baruník, J.; Kocenda, E.; Vacha, L. 2015. Gold, oil, and stocks: dynamic correlations, International Review of Financial Analysis 42: 186-201. http://dx.doi.org/10.1016/j.iref.2015.08.006

Bellalah, M.; Fadhlaoui, K.; Lahiani, A. 2011. The contribution of emerging markets to international diversification, Bankers, Markets \& Investors 110: 31-50.

Berger, D.; Pukthuanthong, K.; Yang, J. J. 2013. Is the diversification benefit of frontier markets realizable bymean-variance investors? the evidence of investable funds, The Journal of Portfolio Management 39(4): 36-48. http://dx.doi.org/10.3905/jpm.2013.39.4.036

Cordella, T.; Gupta, P. 2015. What makes a currency procyclical? an empirical investigation. Journal of International Money and Finance. http://dx.doi.org/10.1016/j.jimonfin.2015.02.018

De Bock, R.; De Carvalho Filho, I. 2015. The behavior of currencies during risk-off episodes, Journal of International Money and Finance 53: 218-234. http://dx.doi.org/10.1016/j.jimonfin.2014.12.009

Errunza, V.; Hogan, K.; Hung, M. 1999. Can the gains from international diversification be achieved without trading abroad?, The Journal of Finance: 54(6): 2075-2107.

http://dx.doi.org/10.1111/0022-1082.00182

Estrada, J. 2008. Fundamental indexation and international diversification, The Journal of Portfolio Management 34(3): 93-109. http://dx.doi.org/10.3905/jpm.2008.706247

Eun, C. S.; Huang, W.; Lai, S. 2008. International diversification with large- and smallcap stocks, Journal of Financial and Quantitative Analysis 43(2): 489524. http://dx.doi.org/10.1017/S0022109000003604

Gaggero, A.; Gaggero, J.; Rúa, M. 2015. The principal characteristics and macroeconomic impact of capital flight in Argentina. Problemas del Desarrollo 46(182): 67-90.

http://dx.doi.org/10.1016/j.rpd.2015.06.002 
Grubel, H. G. 1968. Internationally diversified portfolios:Welfare gains and capital flows, The American Economic Review 58(5): 1299-1314.

Levy, H.; Sarnat, M. 1970. International diversification of investment portfolios, The American Economic Review 60(4): 668-675.

Maurer, R.;Valiani, S. 2003. Hedging the exchange rate risk in international portfolio diversification: currency forwards versus currency options, Managerial Finance 33(9): 667-692. http://dx.doi.org/10.2139/ssrn.499363

Maya, C.; Jaramillo, C. M.; Montoya, L. M. 2011. Is it profitable to hedge exchange rate risk in a global portfolio from the perspective of a colombian investor?, Estudios Gerenciales 27(120): 83-102.

Markowitz, H. 1952. Portfolio selection, The Journal of Finance 7: 77-91. http://dx.doi.org/10.1111/j.15406261.1952.tb01525.x

Markowitz, H. 1959. Portfolio selection: efficient diversification of investments. John Wiley \& Sons. New York.

Markowitz, H. 1987. Mean-variance analysis in portfolio choice and capital markets. Oxford, U.K.: Basil Blackwell.

Markowitz, H. 1991. Foundations of portfolio theory, The Journal of Finance, 46(2): 469-477.

http://dx.doi.org/10.1111/j.1540-6261.1991.tb02669.x

Mishkin, F. S. 2009. Globalization and financial development, Journal of Development Economics, 89(2): 164-169. http://dx.doi.org/10.1016/j.jdeveco.2007.11.004

Ocampo, J. A. 2009. Impactos de la crisis financiera mundial sobre América Latina, Revista de la CEPAL 27: 9-32.
Pastor, M.; Wise, C. 2015. Good-bye financial crash, hello financial eclecticism: Latin American responses to the 2008-09 global financial crisis. Journal of International Money and Finance 52: 200-217. http://dx.doi.org/10.1016/j.jimonfin.2014.11.019

Quinn, D. P.; Voth, H. J. 2008. A century of global equity market correlations, American Economic Review 98(2): 535-540.

http://dx.doi.org/10.1257/aer.98.2.535

Ranaldo, A.; Söderlind, P. 2010. Safe haven currencies, Review of Finance 14: 385-407. http://dx.doi.org/10.1093/rof/rfq007

Santillán, A.; Carlos, J. 2013. Alternatives in international diversification for investment portfolios focused in stocks of Lima Stock Exchange, Contabilidad y Negocios 7(13): 13-32.

Sosa, M.; Ortiz, E. 2015. Exchange rate disequilibria integration and crisis: Canada, México, Japan and United Kingdom vs EE.UU. dollar (1994-2014), Contaduría y Administración 60(Supplement 2): 106-127. http://dx.doi.org/10.1016/j.cya.2015.08.014

Switzer, L. N.; Tahaoglu, C. 2015. The benefits of international diversification: market development, corporate governance, market cap, and structural change effects, International Review of Financial Analysis 42: 76-97. http://dx.doi.org/10.1016/j.irfa.2014.11.010

Walker, E. 2008. Strategic currency hedging and international portfolio investments: an upside-down view, Journal of Business Research 61(6): 657-668. http://dx.doi.org/10.1016/j.jbusres.2007.06.041 